\title{
Contents
}

Acknowledgments xi

Prologue: Selling the Truck xiii

\section{Part l: The Future}

The First Ride 3

$\begin{array}{ll}\text { Insanity } & 7\end{array}$

8903 I

The Man behind the Double-decker Buses I7

A Different Kind of Street $\quad 24$

$\begin{array}{ll}\text { Bus Number II } & 27\end{array}$

Greyhound I: Las Vegas to St. George 30

\section{Part ll: The Land}

Black Hill 4 4I

On the Trail of the Padres $\quad 46$

Río Grande $\quad 50$

$\begin{array}{ll}\text { Casting Lots } & 58\end{array}$

The Crossing of the Fathers 6I

The Network and the Frame 66

$\begin{array}{ll}\text { The Inheritance } & 75\end{array}$

$\begin{array}{ll}\text { Journey to the Center } & \text { 8I }\end{array}$ 
$\begin{array}{ll}\text { Restoration } & 90\end{array}$

$\begin{array}{ll}\text { Recapitulation } & 97\end{array}$

Greyhound II: Salt Lake to Rock Springs IOo

\section{Part III: Opportunity}

Home of Rock Springs Coal $\quad$ I07

Crosswinds $\quad$ IIO

South Pass $\quad$ II5

$\begin{array}{ll}\text { The Biggest Bust of Them All } & \text { I2O }\end{array}$

Independence Rock $\quad$ I24

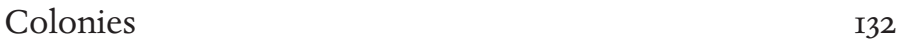

Greyhound III: Casper to Longmont $\quad$ I35

The Most Important Trip of the Day $\quad$ I37

Two Economics $\quad$ I45

Corridor of Opportunity $\quad$ I53

"Hell . . . It Just Exploded” $\quad$ I58

$\begin{array}{ll}\text { T-REX } & \text { I63 }\end{array}$

$\begin{array}{ll}\text { The Equation } & \text { I70 }\end{array}$

$\begin{array}{ll}\text { The Evolution } & \text { I76 }\end{array}$

Greyhound IV: Denver to La Junta $\quad$ I84

\section{Part IV: Freedom}

$\begin{array}{ll}\text { The Junction } & 195\end{array}$

A Corridor of Ideas (Phase One) 199

Órale $\quad 203$

$\begin{array}{ll}\text { The Santa Fe } & 205\end{array}$ 
Death Valley Scotty, the Super Chief, and the Annihilation of Space (Phase Two)

Greyhound V: Flagstaff to Phoenix

The Anti-City (Phase Three)

Why Are People Riding the Light Rail?

Waiting for the Train

A City within Cities

The Ball Boy

The Changing of the Guard 245

A Nice Ride 252

Part V: Adventure

Motoring 263

By the Lincoln Highway 267

Packed Veronica 274

Bank Full 278

The Greenbelt 283

The Boise Bicycle Project 289

The City's Front Door 293

A Low-Friction Lifestyle 296

Greyhound VI: Boise to Portland 300

\section{Part V:: The New Mobility}

Moving in Place 


\section{Prologue: Selling the Truck}

I used to take road trips. On my sixteenth birthday, when I received my driver's license, I inherited my parents' 1988 red and white Isuzu Trooper, a garish, dangerously top-heavy vehicle that was quick to overheat. The Trooper always had a rugged demeanor. We had broken it in-and I emphasize broken - on a drive over Elephant Hill in Canyonlands National Park a week after buying it new. Elephant Hill was a mound of sandstone in the desert that a road pretended to go over, a foreboding barrier for four-wheelers, with steep grades and drop-offs. We banged the undercarriage and dented the tailpipe of our brand-new sport utility vehicle. It was just as well.

I could rally the Trooper a long way at a few hours' notice. I packed a sleeping bag and pad, a Coleman stove, a Gore-Tex coat, and some CDs and I was gone. Within five hours of my Salt Lake City house was enough public land to explore for five lifetimes. I drove the Trooper south to the desert and north to the mountains. My parents always worried that the Trooper wouldn't make it out of the city.

A few years later, after the Trooper died, I bought a silver Toyota pickup truck. I installed a lighted camper shell over its bed so I could sleep in it. 
A few days after I bought the pickup I drove it alone to Oregon-to the Cascades, the coast, then on to Portland. The next year I took my brother to the Olympic Peninsula. I drove the truck to British Columbia and Alberta, Baja and Chihuahua.

Spending time on the road led me to work as a reporter for various newspapers. A job that allowed me to travel the West's byways in search of good stories seemed too good to be true, and I loved chewing up miles in my truck between obscure western places. I camped in the truck a lot. One night my girlfriend and I slept in it to wait out a blizzard in Carbondale, Colorado. We froze in our sleeping bags as the blinking plows scraped up and down Main Street all night. I lived in western Colorado, southern Colorado, northern Arizona, and eastern Utah, but they were more like stops on one long road trip. I kept my stuff in the truck.

As these trips accumulated, I sensed something about the West that I was able to pinpoint only later. The mountains and deserts I explored were plenty scenic, but they possessed something else, and it was this: So many of the aspects of America that defined our country, for better and for worse, had always lay westward. They were the persona Jackson carved out of Appalachia, the designs Jefferson had on Louisiana, the dams Floyd Dominy built on the Colorado, the sublimity John Muir saw in the Sierra. The West was the frontier of a young frontier nation, its biggest mystery box of what might come next. The West owned opportunity, freedom, adventure, and America's most spectacular landscapes. A mobility-addicted nation went fastest in the West. The West had always been a well for what we valued about our country. ${ }^{1}$ Making all of this possible, of course - this big multi-century westward reach - was transportation, and on the road I was part of the story. That's what I felt as I drove all those miles.

When my truck turned ten, we had a party for it. I had driven it in the neighborhood of 150,000 miles, to all ends of North America. By then the road trips had tailed off. I had moved to the Bay Area and my life had been in stasis, on a happy circular track of work, neighborhood, and family. Every day my wife and I woke up our two-year-old daughter. I took her to school. I went to work. I got lunch at the same places at the same time of day. I visited the same sports websites, took a break at the same time, and came home along the same route. We bought a house and rebuilt our yard and sank ourselves into our neighborhood like the young trees we planted. My 
pickup, once the vehicle of choice among my friends and I, seemed out of place among the Priuses and MINIS that populated the area. The truck sat in the driveway.

I sold my truck when it couldn't safely transport our daughter's new car seat. We didn't get much for it. We traded it for a new family car. The man at the dealership who negotiated with me explained that my truck would be bundled with a bunch of other old beaters and put on a barge to Asia, or something like that. An ignoble end for a traveling companion.

As spring came around last year, I got the urge for the road again. I felt cabin fever in the house and in the neighborhood. I had a surfeit of vacation time at work. My list of western places to visit still contained a lot of unchecked items. In my head, I began to plan a solo three-week road trip: California, Nevada, Utah, Oregon-I could cover a lot of ground in three weeks.

But I was also now painfully aware of something about the West that I loved. I had spent the last ten years studying cities in one way or another as a journalist or student or city planner. And having lived in large coastal cities, I had become used to getting around much of the time by modes other than cars. I biked or bused to work and took Bay Area Rapid Transit from my East Bay house to explore San Francisco. I lived in a neighborhood where a three-minute walk led to three grocery stores, a hardware store, a café, a few restaurants, a few bars, a bookstore, a music store, a dry cleaner, and my barber. I drove, sure. I mean, I lived in California. Our house's convenience to Oakland's gazillion freeways was one of its major selling points. But I did not choose to drive with the automation that I did growing up. As with many people my age, cars did not hold the appeal they once did. We realized there were other ways of getting around. We rediscovered the pleasures of walking, of riding a bike, and of public transportation. I reveled living in a place where the other options were close at hand. I started to spend fewer weekends driving to bike rides outside the city and did more biking inside the city. My daughter and I took the train to our adventures.

I knew that having a variety of options for getting around is a rarity in America. We have been the grounds for what Bill McKibben calls the "sunk costs" of oil-dependent auto infrastructure. ${ }^{2}$ What has been best for America is what is best for cars. So eventually people suffered. Where, half a century 
ago, almost half of American school children walked or biked to school, now almost 90 percent do not. ${ }^{3}$ Most of the country cannot walk to their daily needs within ten or twenty minutes, let alone three.

The Interior West is the greatest offender: the square states are a web of freeways tying together knots of mega malls and subdivisions. The places where most of us westerners live are quasi cities that are too spread out to walk in or for mass transit but too close together to be a home on the range. They are perfect for one thing: driving cars. ${ }^{4}$

I had watched it happen. That I drove all those miles in my truck was no accident: the automobile built the West. And at first, automobility had heightened the things that made the West great. We arrived at more spectacular places faster. We lived in farther flung, prettier places where we could remove ourselves from the idea of million-person conurbations but still get to our metropolitan jobs in less than half an hour. The individual freedom that cars seemed to offer was in step with the open vistas of the West. And so we gave ourselves to cars and, outside of historic downtowns and central city neighborhoods, they dictated the shape of the places we lived. This is true throughout America, but it is especially true in the West, where cities emerged as factories began to produce internal combustion engines and grew as the auto became ubiquitous and all-powerful. In the twentieth century, the car paced everything we valued about America's frontier.

But even for a road-loving person like myself, it had become clear that love had become dependence, and dependence had become addiction. And the West's overdependence on autos had put in jeopardy all of these things we loved about it in the first place. Cars, seemingly providing a kaleidoscope of choice, actually narrowed the possibilities for living in such wide-open country. The course of this western experience, while appearing limitless, presented limited options. The enormous returns of mobility and opportunity seen decades before had begun to diminish rapidly.

Perhaps most important, the auto had jeopardized the West's mystic hold on the American future. In the wake of the Great Recession, the West's boom cities appear to be relics of a twentieth-century ethos that rode the auto until it broke down and then bought a new one. Western cities, once paragons of mobility, are constantly threatening to become congested messes. Once fashioned as clear mountain-aired sanitariums to heal the sick, they create some of the worst air quality in the nation. Once unique places that bore a connec- 
tion to their landscapes, western metropolises began to look like everywhere else. ${ }^{5}$ Take, for example, a drive down State Street in Salt Lake City. You start at the hilltop perch of the Utah State Capitol, looking down into the bowl of the Salt Lake Valley, clear across to the sharp peaks of the Wasatch-if the view is not mucked up by smog — and begin heading south, moving through the grandeur of Eagle Gate and the Beehive House, which optimistically marked a new kind of community in the open valleys of the West. As this community grew, State Street, as its name implies, became the string that connected the communities of Utah-eventually, as U.S. Highway 89, reaching to the Arizona border. A ribbon of asphalt and a car provided a day's ride from the Capitol through fruit orchards, Lombardy poplars, and big sagebrush to the far-flung communities of the state. But on the State Street of today it's only a few blocks until you see the toll the auto has taken on this profound road of the West. State Street has become a treeless seven-lane traffic canal that, despite its continuing throughput, produces a hostile public realm for people. Drive on it fifty miles to the southern tip of the Wasatch Front metro area and find few respites from car malls, strip malls, boat malls, empty malls, drive-throughs, drive-ins, drive-ups, double left turns, and Double Whoppers. Dozens of State Streets cross the West, and without the scene of the mountains rising behind them it would be very hard to distinguish one from another. Autos are their means, but they have no ends.

I dare say that cars have betrayed the American West by promising the best things about the West and then breaking those promises.

A big part of the problem is that we hold onto the old meanings of the words that have long defined the West as America's frontier. The ways we define opportunity, freedom, and mobility are too dependent on fossil fuels, freeways, low-density subdivisions, space between people, and free parking lots. Meanings from a mythic past, an insolvent present, and an unpleasant future. I've come to realize that the meanings of these words should evolve. We need to not only reclaim but also redefine these words in the West.

I grew up, I realize now, during the absolute height of automobility. For much of my childhood gas cost less than \$I. Streets in Salt Lake City were wide and uncomplicated. The peak of the industrial dream similarly defined other aspects of life in the I970s and I980s. One of my earliest memories is of sitting in the back of my parents' car in a giant parking lot of a chain drugstore, eating a hamburger from the McDonald's drive-through. 
And that's the thing. Mounting evidence tells us that we have seen the peak of cars. Yes, the private auto still constitutes the way 86 percent of America commutes to work, including 75 percent of us who drive alone. ${ }^{6}$ These figures are even higher in the West, with autos having a 90 percent share of the commutes in most western metro areas. But throughout the 2000s, joining several other upward curves that defined twentieth-century American lifeincome growth, the expanding house, insane real estate appreciation, smoking - driving started to decline. Auto travel appeared to be slowing down for the first time since the invention of the car. The number of miles a person travels in a given time period, called Vehicle Miles Traveled, or VMT, leveled off in 2004 and then began to decline for the next decade. ${ }^{7}$ One researcher estimated that the US VMT in 2010 was Io percent below what it would have been had twentieth-century trends continued. ${ }^{8}$ Although the Great Recession hastened the decline of VMT, the reduction began well before the downturn and has continued through the recovery (Yes, VMT started to increase again in mid-20I4, likely due to plunging fuel prices, but has not returned to the historical trend). By late 2012 the total decline since 2004 amounted to 7.5 percent. This change has affected nearly all of the country's metropolitan areas, ${ }^{9}$ where Americans began to commute less by private vehicle and own fewer cars. ${ }^{10}$

Meanwhile, Americans are once again discovering other ways to get around. The proportion of people who commute by transit in the United States remains small — averaging about 5 percent in the nation's metro areasbut since the 1990s, transit's share of American transportation has grown, especially in recent years. ${ }^{11}$ From 2010 to 20II, as vehicle use declined, transit use jumped by 2.3 percent, reaching its second highest ridership since 1957 (after 2008) and increasing by another 5 percent from 20II to 2012. ${ }^{12}$ According to the Federal Transit Administration's National Transit Database, the total annual miles traveled on public transit increased by 20 percent from 2000 to $201{ }^{13}{ }^{13}$ As more comfortable and classy urban rail systems become available and mobile device applications allow would-be passengers to use GPS to track buses, many people who can afford a car are choosing to ride transit.

The 2000 s also saw a bicycle revolution. The largest changes in America's transportation behavior from 2000 to 2009 stemmed from an increase in city bicycling. ${ }^{14}$ Bicycling's share of commutes in the nation's thirty largest metro areas' central cities increased by almost 60 percent from 2000 to $2009 .{ }^{15}$ 
America is slowly responding to the demand for alternative transportation. ${ }^{16}$ Since 198I a dozen formerly bus-only cities have built light rail systems. ${ }^{17}$ Cities are building bike lanes by the tens of miles. They are becoming serious about walking, rewriting street standards and zoning codes to encourage getting around on foot.

On America's onetime frontier, the same trends are apparent, and in some cases westerners are leading the way. A report by the Maryland Public Interest Research Group found that interior western metro areas for which data was available all experienced declines in VMT for 2006-20II, including Salt Lake City, Tucson, Albuquerque, Spokane, and Denver, whose VMT decreased by over ro percent. ${ }^{18}$ The West offers many of the nation's best new rail systems and has experimented with train-like buses called bus rapid transit. ${ }^{19}$ Western cities with new rail systems are seeing their populations ride transit significantly more, including 33 percent increases in per capita transit miles traveled in metropolitan Salt Lake City and Phoenix and almost a 300 percent increase in Albuquerque. ${ }^{20} \mathrm{~A}$ recent Brookings Institution report ranked the best and worst cities in the United States for transit service to and from work, and all of the top ten cities were in the West. Considering that, unlike the older cities in the East and the Midwest, the largely post-auto metros of the West are building both their transit and transit-supportive communities from scratch, that's remarkable.

In addition, western cities have pioneered bike-sharing programs, doubled and tripled their bike lane miles, and brought mountain trails into urban transportation networks. The West has become home to America's most physically active populations. ${ }^{21}$

Clearly, in the West we have an opportunity to decide which way we want to point our arrow and to reconcile the contradictions between the soul of the West and our servitude to the auto. To redirect all the State Streets. It is clear the car is not going away, nor should it. But what we have are possibilities, options, choices in a world where only one choice existed for the last fifty years.

But back to my road trip. A solo journey by the station wagon that we bought to transport our daughter safely was less appealing than by my departed silver pickup. So I thought of another idea. When I had traveled to other countries, in Europe as well as in South America and Asia, I got around by train and bus without even thinking about it. Who would rent a 
car in those places? Who would want to? I had covered hundreds of miles by train and bus in China and Peru. I had traveled their cities by cabs, trains, bike, and foot without ever looking for parking. Why couldn't I do the same thing at home? And so I became intrigued by the prospect of a carless road trip through the West - what the West would feel like without the speed and convenience of a car or whether it was even possible.

Planning this trip also became an investigation of sorts, and I set out a few parameters for it. First, I would need to understand the West's cities, simply because most westerners lived there. Our lifestyles drove almost everything that shaped the West, from our footprint on the land to our economic opportunities. Changing the West had to happen in the cities. If the places we lived couldn't embody opportunity, freedom, and adventure, how could the rest of the West? I wanted to talk to people in the cities who were changing how we got around them, fundamentally shifting the foundation of the region.

I researched the changes taking place in the ways the urban West got around, and I picked six cities to visit on my trip. These cities embodied the important qualities I saw in the West, in the frontier of America, and were now beginning to rediscover the region's character and identity-and the common thread was ditching the car.

But I would also need to understand the vastness around the cities, the space of the American West. So in between my urban stops I would travel historic routes of the region in order to appreciate the origins of these qualities of the West and America and how we might recapture and reinterpret them. My hypothesis was that these historic routes-Spanish explorations, emigrant trails, railroads, early highways - created and shaped the modern West and the things we liked about it. I wanted to gain a history of the western road trip, if you will. As John Wesley Powell found out I50 years ago, explaining the West requires a mix of adventure and public policy. And I believed that the people I'd encounter in the twenty-first century would be caught in the same themes of this young American province as those in Powell's time. ${ }^{22}$

I drew my route from Las Vegas across the three deserts of the Mojave, the Colorado Plateau, and the Great Basin north to Salt Lake City, across the Rockies to Denver, down the Front Range into the Great Plains, back over the Continental Divide, through the Navajo Reservation and down to Phoenix, then due north a thousand miles to Boise, and finally out nearly 


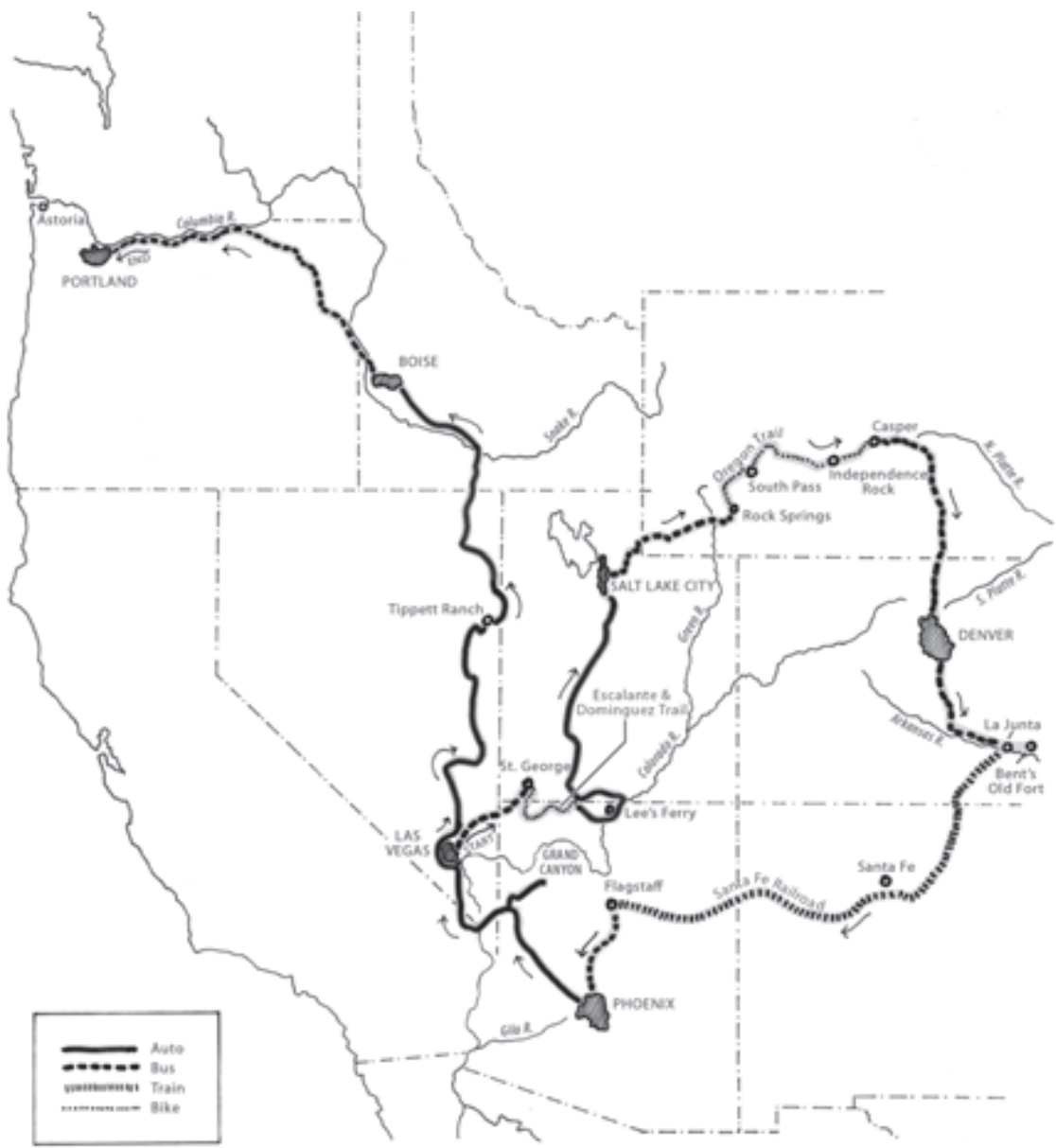

The trip.

to the West Coast to Portland. In a few places, I could not avoid the car, but mostly I found ways to travel without one-by bus, train, and on foot. My bicycle, packed with panniers and decked out with a GPS, would be my principal vehicle.

Each chapter in this book is focused on a segment of this trip. More importantly, though, it is focused on a quality, a characteristic, an ingredient of America that has traditionally been owned by the West: the future, the land, opportunity, freedom, adventure, and mobility. Each of these was born in 
the torturous historic transportation routes I would be exploring. Each was heightened by the automobile, just as each was threatened by overdependence on the automobile. And now, each is experiencing a revival in the cities of the West by people choosing to get out of their cars and explore other ways of getting around. Each of the six chapters follows this story arc: the West created, lost, and reclaimed.

With the auto's hold on the American West seemingly loosening, I set out to see how we are reclaiming America's frontier and the things we love about it. If not the car, what does define the West? I took to the road to find out. 


\section{Notes}

I. By "our country," I mean the United States of America, separate from the Native American nations that lay in its path of westward expansion. The land that, through conquest, became the American West, likely meant different things to these communities and nations.

2. Bill McKibben, Eaarth: Making a Life on a Tough New Planet (New York: Times Books, 2010), 55.

3. According to the National Center for Safe Routes to School, 48 percent of children five to fourteen years of age usually walked or bicycled to school in 1969. In 2009, I3 percent of children five to fourteen years of age usually walked or bicycled to school. "How Children Get to School: School Travel Patterns from I969 to 2009," The National Center for Safe Routes to School, accessed July I6, 20I4, http: / / saferoutesinfo.org/sites / default/files / resources / NHTS_school_travel_ report_20II_o.pdf.

4. And, as we will find out, they aren't even very good for that anymore.

5. This is to say nothing of the use of the auto as a tool to marginalize poor populations and communities. Freeways allowed middle- and upper-class residents to live in distant suburbs while working in the city while fragmenting and cleaving off the urban fabric of working-class communities. This was especially true in the industrial cities of the East, Midwest, and West Coast, but it happened in the Interior West as well.

6. “2009 American Community Survey, " US Census Bureau, accessed July I6, 20I4, http:/ / www.census.gov/acs/www/data_documentation/2009_release/.

7. Eric Sundquist, "Per Capita VMT Ticks Down for Eighth Straight Year," State Smart Transportation Initiative, accessed February 25, 2013, http: / / www.ssti .us/2013/ 02/per-capita-vmt-ticks-down-for-eighth-straight-year/.

8. Todd Litman, "Changing Travel Demands: Implications for Planning," Planetizen, accessed August 22, 2010, http: / / www.planetizen.com/node/ 45665.

9. The proportion of workers commuting by private vehicle-either alone or in a carpool-declined in ninety-nine out of one hundred of America's largest urbanized areas between 2006-20II; the proportion of households without cars increased in eighty-four out of the one hundred largest urbanized areas from 2006 to 20II; and the proportion of households with two cars or more decreased in eighty-six out of the one hundred largest urbanized areas from 2006 to 20Ir. See "Transportation in Transition: A Look at Changing Travel Patterns in America's Biggest Cities," Maryland PIRG, last modified December 4, 20I3, http: / / www.marylandpirg.org / reports/mdp/transportation-transition. 
Io. The 2000 s were the first decade since the automobile era began in 1900 in which the number of vehicles per person was smaller at the end of the decade than at the beginning. See Norman Garrick, "The End of the Automobile Era?” Planetizen, last modified April I2, 20I0, http: / / www.planetizen.com/node/4373I.

II. A study by Steven E. Polzin and Xuehao Chu concluded that in the last few decades transit trips had risen overall. Polzin and Chu found that transit trips declined in the early I990s, followed by ridership growth through 200I, at which point ridership began declining again before rising in 2004. "A Closer Look at Public Transportation Mode Share Trends," US Department of Transportation, Bureau of Transportation Statistics, Journal of Transportation Statistics 8, no. 3, accessed July I6, 20I4, http: / / www.rita.dot.gov/bts/sites/rita.dot.gov.bts/files/publications /journal_of_transportation_and_statistics/volume_08_number_03/html/paper_03 /index.html.

I2. "Io.4 Billion Trips Taken On U.S. Public Transportation In 20Ir: Second Highest Annual Ridership Since 1957," press release, American Public Transportation Association, last modified March I2, 20I2, http: / / www.apta.com/mediacenter / pressreleases / 2012/Pages/I203I2_20IIRidership.aspx.

I3. "Transportation in Transition," Maryland PIRG.

I4. A key force underlying these changes appeared to be a major generational shift in how Americans viewed urban life, which is to say, life for 80 percent of us. American cities had found new vitality as the focus of the latest generation to come into adulthood. This millennial generation was less likely to want to own a car and more likely to want to live in an urban place. In 2008, 82 percent of twenty- to twenty-four-year-olds had their driver's license, down from more than 87 percent in 1994, according to the Federal Highway Administration. The percentage of new cars sold to twenty-one- to thirty-four-year-olds hit a high of nearly 38 percent in I985 but stands at around 27 percent today. Allison Linn, "Carmakers' Next Problem: Generation Y: People in Their Teens and Twenties Are More Interested in Gadgets than Cars," NBC News, last modified November 4, 2010, http: / www .nbcnews.com/id/39970363/ns/business-autos/t/ carmakers-next-problem -generation-y/.

15. Yonah Freemark, "Transit Mode Share Trends Looking Steady; Rail Appears to Encourage Non-Automobile Commutes," The Transport Politic, last modified October 13, 20I0, http: / / www.thetransportpolitic.com/2010/Io/I3/transit-mode -share-trends-looking-steady-rail-appears-to-encourage-non-automobile-commutes/.

I6. In March 20I0, the US Department of Transportation (DOT) announced a new bike and pedestrian planning policy "to incorporate safe and convenient walking and bicycling facilities into transportation projects. Every transportation agency, including DOT, has the responsibility to improve conditions and opportunities for 
walking and bicycling and to integrate walking and bicycling into their transportation systems. Because of the numerous individual and community benefits that walking and bicycling provide - including health, safety, environmental, transportation, and quality of life - transportation agencies are encouraged to go beyond minimum standards to provide safe and convenient facilities for these modes." http:// www.fhwa.dot.gov/environment/bicycle_pedestrian/overview/policy_accom.cfm, accessed March 15, 2010.

I7. Eric Jaffe, "Can Light Rail Carry a City’s Transit System? It Can If It’s Built Right, As in Portland Or San Diego, and New Research Explains Why," Citylab, last modified August I, 20I2, http:/ / www.citylab.com/commute/20I2/ 08/can-light -rail-carry-citys-transit-system/2786/.

18. "Transportation in Transition," Maryland PIRG.

19. Adie Tomer, Elizabeth Kneebone, Robert Puentes, and Alan Berube, "Missed Opportunity: Transit and Jobs in Metropolitan America," Brookings, last modified May I2, 20II, http:/ / www.brookings.edu/research/reports/20II/05/I2-jobs-and -transit.

20. "Transportation in Transition," Maryland PIRG. The Salt Lake City metro area's per capita transit passenger miles traveled (PMT) increased from I38 to I74 (with the new TRAX light rail system); Phoenix's increased from 82 to IIo (with the new Valley Metro light rail system; and Albuquerque's increased 2I to I29 (with the new Rail Runner commuter rail system). These were all top-twenty-in-the-nation increases.

2I. Seven of the top ten states with the highest percentages of highly physically active adults were in the West. "State Indicator Report on Physical Activity, 20го," Department of Health and Human Services, Centers for Disease Control and Prevention, accessed July I6, 20I4, http:/ / www.cdc.gov/physicalactivity/downloads /PA_State_Indicator_Report_2oro.pdf.

22. And while it may seem odd to place the muddy theories that drive the shaping of cities alongside the clear(er) narratives of history—after all, city planning and western history each have their own canons, jargon, stories, and professions-each works at one end of the short timeline of the same remarkable American region; they can't help but to inform one another. 